\title{
REALIZATION OF MILK PRODUCTIVITY \\ OF HOLSTEIN COWS OF DIFFERENT AGE \\ ON THE INDUSTRIAL COMPLEX OF MILK PRODUCTION
}

\section{Pishchan Ilona ${ }^{1}$ \\ Lytvyschenko Liudmyla ${ }^{2}$}

DOI: https://doi.org/10.30525/978-9934-571-89-3_105

Among the cows of milk production especially popular in our country the Holstein breed of cows, this was introduced by breeders in the 19th century in the USA. Herds of Holstein cattle have a high genetic potential of dairy production, and many animals have a record productivity [1, p. 2]. The highest average daily milk-yield in most cows is, as a rule, in the second month of lactation, and as lactation increase, they certainly decrease. The longer the period of lactation, the less specific gravity in it in the first months with a high average daily productivity of the animal [2, p. 15]. Increasing the duration of the service-period naturally leads to an increase of days of the dairy and the total lactation fee. At the same time, increased the milk-yield during the 305 days of lactation, and with the prolongation of the service-period increases the time a reduced productivity in cows as a result of pregnancy [3, p. 3]. In modern conditions of industrial production of milk, the service-period in high productivity cows is substantially lengthened, that's why the lactation period at 340-360 days is considered normal.

In the conducted researches, the average duration of one productive period in Holstein cows from the first to the sixth lactation was at the level of 342.1-351.5 days. Taking into account the dry off time before the next calving, the duration of the period between calving of these experimental animals slightly exceeded the norm and amounted to an average of 400.2-410.5 days. Considering the level of milk productivity of Holstein animals for the entire period of lactation, it should be noted that it increase from the first-heifers of the first lactation, acquired the maximum value in cows on the third and remained practically identical in animals during the fourth, fifth and sixth lactation. Thus, $7747.7 \mathrm{~kg}$ of physical or $7532.6 \mathrm{~kg}$ of $4 \%$ milk was obtained from the first-heifers, which inferior to the indicator of cows in the second lactation, in which the milk-yield was an average of $8597.8 \mathrm{~kg}$ and $8245.8 \mathrm{~kg}$ of $4 \%$ milk, respectively, at $10.9 \%(\mathrm{P}<0.001)$ and $9.5 \%(\mathrm{P}<0.001)$.

\footnotetext{
${ }^{1}$ Dnipropetrovsk State Agrarian and Economic University, Ukraine

${ }^{2}$ Dnipropetrovsk State Agrarian and Economic University, Ukraine
} 
The productivity of Holstein cows in the third lactation was on average $9422.2 \mathrm{~kg}$ of physical or $9220.0 \mathrm{~kg}$ of $4 \%$ milk, which was higher than the animals of the second lactation, respectively, by $8.8 \%(\mathrm{P}<0.001)$ and $10.6 \%(\mathrm{P}<0.001)$, and in comparison with the first-heifers, such an excess was already $17,8 \%(\mathrm{P}<0.001)$ and $18,3 \%(\mathrm{P}<0.001)$.

High and almost identical level of milk production was observed in cows with the fourth and fifth lactation in which the physical milk-yield was 9694.3 and $9665.4 \mathrm{~kg}$, or 9551.3 and $9548.6 \mathrm{~kg}$ of $4 \%$, which was higher, the indicator of productive animals of the third lactation, respectively, by 2.8 and $2.5 \%$.

The productivity of Holstein cows in the sixth lactation was on average $9499.3 \mathrm{~kg}$ of physical or $9276.0 \mathrm{~kg}$ of $4 \%$ milk, which was higher than the index of first-heifers respectively by $18.4 \%(\mathrm{P}<0.001)$ and $18.8 \%(\mathrm{P}<0.001)$.

The researches have established that in the normal duration of lactation, there is practically no correlation between the livestock and the live weight of Holstein cows. Moreover, in first-heifers and cows of the third lactation, this dependence was $r=0.155$ and 0.033 respectively, then in the cows of the second to sixth lactation, this dependence was generally negative $-r=0.160-0.280$.

Having a high genetic potential of milk production, Holstein cows were still characterized by uneven levels of physiological activity, in recount to 305 days of lactation. So, if the cows in the fourth, fifth and sixth lactations for one day accounted for $29.0-29.7 \mathrm{~kg}$ of secreted physical or $28.3-29.2 \mathrm{~kg}$ of $4 \%$ milk, then the animals of the third lactation the figures were 28.9 and $28.3 \mathrm{~kg}$, which inferior to the value of cows in the fourth lactation respectively by 2.77 and $3.18 \%$.

Insufficient level of activity during this period was in the second lactation of cows, which was $26.4 \mathrm{~kg}$ of physical or $25.4 \mathrm{~kg}$ of $4 \%$ milk per day. These indices were inferior to the values of the cows fourth lactation, respectively, by $12.5 \%(\mathrm{P}<0.001)$ and $14.9 \%(\mathrm{P}<0.001)$. The lowest physiological activity of the organism was in the first-heifers, which for one day secreted only $23.6 \mathrm{~kg}$ of physical or $22.94 \%$ milk, which was lower than the indicators of third lactation cows, respectively, $22.5 \%$ $(\mathrm{P}<0.001)$ and $23.6 \%(\mathrm{P}<0.001)$, and by $25.9 \%(\mathrm{P}<0.001)$ and $27.5 \%(\mathrm{P}<0.001)$ compared to the values of the fourth lactation cows.

Experimental Holstein cows of all ages are characterized by high rates of milkyield. Thus, the cows in the third lactation had this coefficient at the level of $15.1 \mathrm{~kg}$ of milk per unit of live weight. In the fourth lactation, this coefficient was at $15.5 \mathrm{~kg}$, which exceeded the value of animals of the third lactation by $2.58 \%$. With the age of lactating cows, dairy coefficient continued to increase and in cows by the fifth lactation was an average of $15.6 \mathrm{~kg}$, which was greater than the value of third lactation cows by $3.21 \%$. Only in the sixth lactation dairy coefficient of cows slightly decreased to $15.0 \mathrm{~kg}$. At the same time, significantly lower milk-yield was observed in animals in the second lactation, in which it did not exceed $13.9 \mathrm{~kg}$, which is inferior to the value of cows in fifth lactation by $12.23 \%(\mathrm{P}<0.001)$. Insufficient dairy coefficient was observed in the first-heifers, in which it did not exceed $12.8 \mathrm{~kg}$, which was lower than the value of animals of the second lactation at $7.91 \%$ $(\mathrm{P}<0.01)$, and compared with cows of the third lactation - by $17.97 \%(\mathrm{P}<0.001)$. 
As O. M. Dundukova and others note (2009) in terms of the amount of milk fat and protein obtained from the animal for the entire productive period, can most objectively judge the intensity of the use of cows in the herd [4, p. 75].

Researches have shown that the production of milk fat for the entire lactation period was high and practically the same in animals by the fourth and fifth lactation and amounted to an average of $378.5 \mathrm{~kg}$. Only slightly lower this product was in cows by the third and sixth lactation, which was at the level of $363.4-365.1 \mathrm{~kg}$, which was lower than the animals of the fourth and fifth lactation at 3.59-4.07 \%.

At the same time, a significantly lower indicator of milk fat was characterized by the animals in the second lactation, which produced $320.4 \mathrm{~kg}$, which was less than the value of the cows of the sixth lactation at $13.95 \%(\mathrm{P}<0.001)$, and animals of the fifth lactation were $18,23 \%(\mathrm{P}<0.001)$. A low indicator of milk fat was characterized by the first-heifers, whose $295.6 \mathrm{~kg}$ was secreted, which was $8.39 \%$ higher than the second lactation $(\mathrm{P}<0.01)$.

According to the indicator of production milk protein, the highest value was observed in cows in the fourth lactation $-319.1 \mathrm{~kg}$. At the same time, only slightly lower this indicator was characterized by animals in the fifth lactation $-313.7 \mathrm{~kg}$.

The lowest production of milk protein were characterized by first-heifers, who, during the first lactation period, secreted only $255.0 \mathrm{~kg}$, which was lower than the value of the second lactation cows by $10.86 \%(\mathrm{P}<0.001)$, and compared with the indicator cows of the sixth lactation - by $25.14 \%(\mathrm{P}<0.001)$.

In total, the production of milk fat and protein was the highest in cows in the fourth and fifth lactation and amounted to an average of 697.6 and $692.5 \mathrm{~kg}$. Only a slightly lower indicator was the cows of the third and sixth lactation, in which this value was at the level of 669.8 and $671.4 \mathrm{~kg}$, respectively. Low milk fat and protein production was noted by animals in the second lactation, which produced an average of $6032 \mathrm{~kg}$, which was by $11.04 \%$ ( $\mathrm{P}<0.001)$ less than the third lactation cows. The lowest value of the production of the main components of milk was characterized by the firstheifers, in which it did not exceed $550.5 \mathrm{~kg}$, which was lower than the rate of second lactation cows by $9.57 \%(\mathrm{P}<0.001)$, and compared with the indicator of animals of the third lactation - by $21.67 \%(\mathrm{P}<0.001)$.

In general, Holstein cows characterized by high adaptive properties, under which the adaptation index was only slightly lower than the neutral value. Thus, in cows of the third to fourth lactation, the adaptation index was on average $3.1 \pm 0.19$ units. A lower adaptation index was observed in the first-heifers and cows of the fifth lactation, which averaged $-3.3 \pm 0.23$ and $-3.3 \pm 0.19$ units. Cows in sixth lactation were characterized by an adaptation index at the level of $-2.9 \pm 0.20$ units, which was lower than the value of the first-heifers by $13.8 \%$.

Thus, the realization of the genetic potential of milk yield of Holstein cows during economic use increases from the first to the fourth lactation, and the fifth and sixth, due to physiological exhaustion, tends to some decrease. In the normal duration of the lactation period and high milk production, there is no functional dependence between the livestock and the live weight of cows, and the norm of reaction to the conditions of exploitation is close to the neutral value. 


\section{References:}

1. Kalashnikov V. V., Amerkhanov X. A., Draganov I. F. i dr. (2005). Zhivotnovodstvo Rossii. Sostoyanie i napravleniya povysheniya effektivnosti [Animal husbandry of Russia. Condition and ways of increasing efficiency]. Zootekhniya, no. 6, pp. 2-8. (in Russian)

2. Petkevich N. (2000). Prodolzhitel'nost' produktivnogo ispol'zovaniya korov i prichiny ikh vybrakovki [Duration of productive use of cows and the reasons for their culling]. Molochnoe $i$ myasnoe skotovodstvo, no. 1, pp. 15-17. (in Russian)

3. Afanasenko V. A. (2000). Otsinka uspadkovanosti oznak vidtvornoyi zdatnosti molochnykh koriv [Assessment inheritance of characteristic of reproductive ability of dairy cows]. Naukovotekhnichnyy byuleten' Instytutu tvarynnytstva, Kharkiv, issue 80, pp. 3-5. (in Ukrainian)

4. Dundukova E. N., Kokhanov M. A., Zhuravlev N. V., Ignatov A. V. (2009). Produktivnoe dolgoletie korov $\mathrm{v}$ zavisimosti ot ikh lineynoy prinadlezhnosti [Productive longevity of cows depending on their linear affiliation]. Izvestiya Nizhnevolzhkogo agrouniversitetskogo kompleksa, no. 3 (14), pp. 75-80. (in Russian) 